Medical Congress held in London in 1881 hypermetropia was considered sufficient to exclude a man from being a sailor if before the age of eighteen he had one dioptre of manifest hypermetropia. ${ }^{10}$ In the British navy it is the rule, I believe, that officers are allowed to wear glasses after they have attained a certain rank, and there seems to be no satisfactory reason why this rule should not be considerably extended. If a hypermetropic officer can only read $\frac{6}{6}$ with glasses it should be not only allowable but compulsory that he should correct his refraction, and then the exact number of dioptres of his hypermetropia is of little consequence.

Bath.

\section{REMARKS ON THE HISTORY AND DIS- CIPLINE OF ENGLISH PRISONS IN SOME OF THEIR MEDICAL ASPECTS.}

By R. M. GOVER, M.D. ST. AND., F.R.C.P. LoND., MEDICAI INSPECTOR OF PRISONS.

IN the winter of 1773-74 John Howard made that celebrated journey which has been so graphically described by the late Dr. W. A. Guy, ${ }^{1}$ and from which journey may be said to have originated the great prison reforms that have been in progress in England during the past 100 years. From the late autumn of 1773 to the spring of 1774, says Dr. Guy, there might have been seen, now at one country town, now at another, first of the midland districts of England, then of parts more remote, a gentleman on horseback, followed by his groom. It was not a time of the year when men take pleasure trips, and it was obvious that the gentleman had some serious business in hand, for he alighted at the county and borough gaols and spent some time there. Thence he would make his way to an inn, order the usual dinner for the good of the house, spread his notebook before the fire, and make a frugal meal of tea, bread, and (if he could get it) fruit. This gentleman was no other than John Howard, the lately appointed High Sheriff of the County of Bedford, the model landlord of Cardington, and he was travelling about in search of a precedent. He would find, if he could, one case at least in which the justices of the peace paid the gaoler of a prison a fixed salary. Had he succeeded he would have gone back to Bedford, near which town he lived, and would have strengthened the hands of the justices with a precedent, without which they had told him they could not act. But happily Howard failed. He could find no single instance in which a gaoler was paid a fixed salary. In lieu of salary the gaoler was allowed to charge certain fees, and these fees had to be paid by every prisoner, whatever the way in which he became such, and be paid before he could be permitted to leave the prison. He might be a poor debtor; he might be innocent of the crime with which he was charged and have been acquitted; or the grand jury might not have found a true bill against him; he might be a petty offender committed for some small theft, or a pressed man with home ties and duties, innocent of everything but not having a stomach to fight; or a man of violence-a highwayman, a burglar, a murderer ; or a treacherous, fraudulent scoundrel, a forger, a receiver of stolen goods, a monster, a chronic fraud, or, perhaps, a raving madman. Whatever he was he must pay the gaoler's fees or remain in prison. The consequence was that innocent men by the thousand were kept locked up in prisonmany for years or for life; many to die there, victims of gaol fever, confluent small-pox, and the other fatal maladies which spring out of the want of the prime necessaries of life-food, water, fuel, clothing, air, and exercise; some to be lashed into madness and some to lapse into fatuity. Howard could find no precedent for a better system of payment, but the winter's journey was not made in vain. He collected a mass of facts that at once led to great amendment of the law, and struck the death blow to the grossest and most nauseous tyranny that was ever suffered to reign in the midst of a free people. The winter's journey was not only no pleasure trip, but was one surrounded by incidents of

10 Transactions of the Ophthalmelogical Society, vol. ii., p. 195. 1 John Howard's Winter Journe y. By William A. Guy, M.B.,
F.R.C.P., F.K.S., \&c. De la Rue and Co. 1882. danger and disgust as perilous as they were repulsive. When Howard went to his inn after the work of the day he used to spread his notebook before the fire. This he did that he might drive off the foul air it had absorbed in the prison. So foul was this air that many gaolers and even surgeons to gaols made excuses and would not go with Howard into the felons' wards. But nothing could appal him or turn him aside from the path of duty that he had chosen. This journey in search of a precedent, which revealed to Howard in all its revolting details the inner prison life of England, was the first step taken towards prison reform. Dr. Guy states that when, on the motion of $\mathrm{Mr}$. Whitbread, Howard was summoned to lay his facts and figures before the Committee of the House of Commons, he left the House no alternative but immediate action. Two Acts were passed, the one abolishing the obnoxious payment of gaolers by fees, the other for preserving the health of the prisoners and preventing the "gaol distemper." In 1778 the Penitentiary Act was passed. This Act, which was permissive, provided for the placing of prisoners in cells alone, and it gradually came to be adopted in some of the county and borough prisons. But the cost of construction and the prejudice against separation created by the reports as to the results of the "solitary" system in America retarded the progress of a great reform. In 1784; rules were drawn up for the treatment and classification of prisoners, and in 1791 the Courts of Quarter Sessions became in some degree responsible for the periodical visitation and inspection of county and borough prisons. ${ }^{2}$

In the last decade of the last century the virulent gaol fever seems to have disappeared from prisons, though it is certain that a fever in no way distinguishable from gaol fever existed on board H.M.S. Colossus in 1796. This ship took on board, in the autumn of the year, a crew composed entirely of raw landsmen, the worst, according to Dr. Trotter, the fleet medical officer, that ever entered a man of war, of whom a great part had been discharged from gaols; and three or four times during the fitting of the ship fever broke out, one man falling ill, and then all the members of his mess. The disease made its appearance again during the cruise off the coast of Holland. Dr. Guy remarks that we owe to Dr. Trotter one of the most striking illustrations of the fact that a fever in all respects similar to the fever that formerly prevailed in prisons will break out on board ship when unwholesome conditions prevail, as starvation and cold, a scanty supply of impure water, deprivation and pollution of air, exclusion of light, idleness, filth, listlessness: and grief. The French fleet which encountered ours on the glorious June 1st, 1794, was placed under the serious disadvantage of having such a fever on board all its vessels, while Dr. Trotter had "organised victory" by causing" Lord Howe's fleet to go into action without a sick sailor on board. Slow but sure progress continued to be made in English prisons, and in 1818 there were few prisons without a chaplain. But even at this date no systematic employment had been found for the inmates of prisons; idleness prevailed in many county and borough gaols, and overcrowding was excessive. Nevertheless, the conditions were not such as to generate gaol fever. In 1835 and 1839 Acts were passed which further improved the administration of prisons, and inspection by Government officers was provided for; but it was not until 1865 that the provision of a separate cell for each male prisoner became compulsory. Even now legislation remained in great measure a dead letter. owing to the fact that administration remained in the hands of independent local authorities, who failed to provide the requisite buildings, and were without experience save such as was gained by each in its own small area. The last great step. in the direction of reform was taken in 1878, when the local prisons were transferred to the Government, and uniformity of administration for the first time became possible. There were then 113 local prisons in England and Wales; and such has been the effect of consolidation and concentration of authority that the number has been reduced to fifty-seven, with great and good results, the least of which is a large annual saving in the cost of management. Prisoners before trial are kept apart as far as possible from those undergoing sentence, they wear their own clothing (if it is not "utterly vile," as is often the case), they may provide their own diet, and may communicate freely with their friends. After sentence the prisoner beoomes amenable to the progressive

2 The excellent and entertaining work by Major Arthur Griffiths, entitled "Secrets of the Prison House" (Chapmatl and Hall, 1894), contains most valuatle intormation as to the bistory and management of prisons in this cout try. 
stage system, and may raise himself by degrees to the fourth or highest stage, each promotion being attended with the acquisition of some privilege, as, for example, a larger supply of books and more frequent communication with friends and relatives. During all this time, and, in fact, during the whole period of his sentence in a local prison, the prisoner sleeps, takes his meals, and (usually) works in a separate cell. He is subjected to what is termed "separate confinement." This term is apt to convey to persons not familiar with the subject an erroneous improssion of the conditions under which a prisoner is placed when undergoing confinement in a local prison. Although he is separated from other prisoners he is not left in solitude. He is visited frequently by various officers, he is well cared for, and his existence is rendered very endurable. Unless it be for idleness or misconduct he is not subjected to any depressing punishment. As I have previously remarked, ${ }^{3}$ "instances are not wanting to show that separate or even solitary confinement for long periods is consistent with perfect mental and bodily health. The monks of the Grande Chartreuse live alone, each in his own 'cellule.' They remain silent for years, and hear nothing but the sound of their fellow monks' voices at the chapel services, yet visitors never fail to be struck with their healthy and contented appearance. Their food is simple but nutritious, and they are well provided with employment, so that their condition of life may be fairly compared with that of prisoners undergoing separate confinement at the present time in this country." It was not until the completion of Pentonville Prison that separate confinement was carried out continuously on a large scale and in a systematic manner, the results being recorded in detail in reports accessible to the public. Pentonville Prison was opened in December, 1842, and the Commissioners appointed for the government of the prison made favourable reports as to the condition of the prisoners from year to year until 1853, when the then new established convict system was in full operation, and the prison came under the control of the Directors of Convict Prisons. The deterrent and reformatory effects of imprisonment were attained without injury either to the bodily or mental bealth of the prisoners. There was but little sickness among them, cases of insanity originating in the prison occurred but seldom, and deaths were few. It appears evident from the minute detail into which the Commissioners enter in their reports, and from many of the expressions employed, that they were apprehensive of evil or misfortune of some kind, but these apprehensions were not justified by the result. In conseque nce of the success of the system of discipline carried out at Pentonville Prison a large prison after the same model was erected at Wakefield, and separate confinement was carried out there, with even fewer mental cases than occurred to Pentonville Prison. The same system in all its main features has been carried out, and continues to be carried out up at this day, in that and other local prisons without the occurrence of any cases of mental or bodily affection that can be reasonably ascribed to the influence of separate confinement.

In the consideration of the question as to what amount of separate confinement may be borne with safety the experience of the present Board of Commissioners during the last seventeen years appears to me to be of much greater importance than any recorded experience of former times. "The conditions forty or fifty years back" (I quote the memorandum to which I have already referred) "were not those of to-day. Sanitary science has advanced, construction has improved, the causes of disease are better understood, discipline and diet have been modified and changed, and experience has ripened. That experience shows that separate confinement under present conditions is not injurious to the mental or bodily health, and may be continued indefinitely." Separate confinement (using the term in its technical prison sense) lends itself well to any modifications that may be deemed necessary, in the case either of individuals or bodies of prisoners, and is compatible with the carrying out of industrial labour in workshops or with ontdoor labour of any kind available. At whatever work the prisoner might be employed he would still sleep and take his meals in his own cell, which he would, in fact, occupy in the evening and at all times when not at work or at exercise or at the chapel services. The medical aspects of prison discipline as now conducted in this country have some of them been presented in my annual notes appended to the

3 See Memorandum on Separate Confinement, p. 49 of the Report of
Reports of the Commissioners and Directors, and are all of them full of interest. It is not my object to enter into elaborate particulars in this short paper, which deals only with generalities, but there are one or two points to which I may call attention without entering into any tedions statistical or technical detail. Fever of any kind is now of rire occurrence in the prisons of this country, and when it does occur is usually imported, while diseases indicative of defective sanitary arrangements, as erysipelas, are conspicuous by their absence, notwithstanding that many of the inmates of prisons are drawn from quarters where infectious diseases are rife. The average daily population of the local prisons of England and Wales for the six years commencing April 1st, 1888, was 14,119. The mean annual death-rate for this period was $7 \cdot 6$, and the mean annual rate (per 1000 of the population) of releases on medical grounds was 4.5. Reckoning, however, the releases on medical grounds as deaths, and adding them to the actual deaths, the mortality was $12 \cdot 0$ per 1000 per annum for the period of six years. To count all the releases on medical grounds as deaths is, however, unfair to the prisons, seeing that prisoners are frequently released for diseases that may not be fatal, as chronic abscess, debility, abdominal tumour, cataract, paralysis, bronchitis, and so forth. A deduction of at least 25 per cent. for these cases should be made before the influence of releases on medical grounds on the death-rate can be accurately estimated. Making that deduction, the death-rate per 1000 per annum for the six years ending March 31st, 1894, may be fairly represented by the figure $10 \cdot 9 .^{4}$ It may be doubted whether by any future efforts the ratio can be reduced materially below that point.

The number of cases of insanity proportionally to the population of the local prisons of England and Wales will appear very high or very low, according to circumstances and the way in which the matter is presented. If all persons remanded to prison for medical observation, and reported to the police authorities to be insane, are credited to the prisons, the number will appear to be very large; and if to these are added those who are found to be insane within a very short period of reception, as well as those found insane on arraignment or on trial, the number can be made to rise to the extravagant figure of 200 or more per 10,000. But if only those insane prisoners are taken into account who have been sufficiently long in confinement to render it possible that the insanity may have originated and developed in prison, the number will be very small. Everything depends upon the statistical method employed It does not, of course, follow that a prisoner is sane when he is admitted into prison because no symptoms of insanity happen to be manifest at that particular moment. The Rer. W. D. Horrison, in his evidence before the late Depart mental Committee, ${ }^{5}$ mentions the case of a man who was six months or more in Wakefield Prison before it was discovered that he was insane. The Rev. Mr. Morrison says: "I was convinced that he was insane, but the doctor could not find any trace of it, and I could not find any definite trace of it for some time, but one day he was talking to me, and he said, 'I am the man that tried to shoot the Duke of Edinburgh at Melbourne.' That was his delusion, that he was the man that tried to shoot the Duke of Edinburgh at Melbourne, and that is how it came to be found out." And yet according to the method of the Rev. Mr. Morrison himself, this case would have gone to swell the number of cases in which insanity arose in prison, and were (in his opinion) probably caused by prison treatment. The evidence of Mr. Stone, the chairman of the Visiting Committee of Birmingham Prison, before the late Departmental Committee, is probably as con clusive as a formidable array of statistics, and is decidedly more racy and interesting. I may premise that the prison at Birmingham may be taken as a representative prison, and that there is no reason to suppose that it differs in the smallest particular from other local prisons in respect of discipline and management.

Q. 2681.- The Chairman (Mr. Herbert Gladstone): You say that you think that insanity in the Birmingham Prison is very rare? - Very rare indeed. Our returns of insanity are about 0.02 . We have a mere nothing of it.

"2682.-And those cases that you have come in you do not think have been affected by prison?--Sometimes it is the

4 See Appendix No. 21, p. 88, of Seventeenth Report of Commissioners

of Prisons.

5 See Question 3018, p. 105 
result of delirium tremens; that is really in the system before they come in.

"2683. - You have no reason to think that the prison discipline acts upon them?-No; I have very carefully watched them, and I have had a large mass of figures got out to produce to you if you want them, but it is not 1 per cent., it is not a quarter of 1 per cent., and we have 8000 prisoners who went through the gaol last year."

Before concluding this brief paper it may perhaps be interesting and instructive to glance back along the century now about to expire and to compare the English prisons of 100 years ago with those of the present day. In 1795 convicts were herded together in hulks, in which no attempt was made to check the evils of association, and "vice, profanity, and demoralisation" ran riot. Great evils-among them the indiscriminate crowding together of prisoners - were still prevalent in the county and borough prisons, but the reports of John Howard had begun to alarm the national conscience, and justices were beginning to visit and inspect these prisons at periodical intervals. There were nearly 600 prisons in the United Kingdom. In many of them no attempts were made to divide the males from the females, gaol fever was still prevalent, and horrible scenes of wickedness were occasionally enacted. John Howard had made his final journey through Holland, Germany, Prussia, and Livonia to Russia and Lesser Tartary, and had been laid to rest at Cherson, in Russia, where his remains have lain undisturbed to the present day; he had travelled 60,000 miles, and it is believed that he spent from first to last $£ 30,000$ of his own money in the prosecution of his self-imposed duties. If he could now revisit this country he would find that each inmate of the local prisons has a cell of a capacity of about 800 cubic feet to himself, and that this cell, which is in the cleanest condition possible, is furnished with special arrangements for the withdrawal of used-up air and the supply of fresh air. $\mathrm{He}$ would observe that the furnishing of the cell, though not luxurious, is sufficient for the needs of the prisoner; and he would also observe that the prisoner is supplied with the necessary utensils, with good food, with abundance of water, with books, and with a bell-pull by means of which he can draw the attention of the officer of the ward. He would find that the food is sufficient and well prepared, that a well-arranged hospital js provided for the care and treatment of the sick, and that on the expiration of his sentence Discharged Prisoners' Aid Societies are ready to take him in hand and to assist him in making a fresh start in life. Although the prison system of the present day in this country, like other human institutions, may not be perfect, it may be questioned whether the next hundred years will witness evolutionary changes comparable to those that have taken place in British and Irish prisons since 1795. The next great step would seem to be the recoonition by society of its duties in the direction of the prevention of crime, and the discharge of its duties in such a manner as to convert the possible criminal into a useful member of the commonwealth. Whether the somewhat pessimistic doctrines of the criminal anthropologist be accepted as the basis of action, or the more hopeful view of those who regard a proclivity to the commission of crime as the natural outcome, in the majority of cases, of unfarourable surroundings from infancy upwards, there can be no doubt that the criminal elements in society may be largely reduced by such social reforms as the prevention of overcrowding, by attention to the details of sanitation, by judicious education, and by such training as will tend to eradicate habits of idleness. A distinctive feature in the character of the habitual criminal is a distaste for regular labour. The changes that are destined to take place in prison administration, and the measure in which society will interfere to prevent the genesis of the criminal during the next century, cannot, perhaps, be even roughly indicated, but it cannot be doubted that the good work initiated by John Howard will be continued in such manner and with such effect that some, at least, of the criminal classes will lose their characteristics as criminals, and will be finally absorbed into other classes of the social organisation.

St. Quintin-avenue, W.

Mr. George Mülter, of Ashley Down Orphan Houses, Bristol, reached his ninetieth birthday a few days ago, and has received numerous presents and congratulations from friends in all parts of the country.

\section{CASE OF HÆMATOCELE SUPERVENING ON AN ABORTION.}

By J. O'REILLY, M.B. Dubl., M.CH., SURGEON-LIEUTENANT-COLONEL, ARMY MEDICAL STAFF.

THe subject of this case was a woman about twenty-eight years of age, strong and healthy. She had been married four months and was about three months advanced in pregnancy. She had just returned from a long journey from a distant part of Germany, and had experienced a very rough passage across the channel. On Oct. 8th, 1894, the day after her return to Guildford, severe intermittent pains in the lower part of the abdomen set in. On being called to see her I found the uterus firmly contracted and all the symptoms pointing to an impending abortion. During the next two days there were frequent uterine pains. Perfect rest in bed was enjoined and opiates administered. About 8 A.M. On the morning of the 11th I received an urgent summons to see her, and I asked my friend Mr. Sells of Guildford to accompany me. On our arrival we found that an abortion had taken place and that an immense quantity of blood had been lost. A large chamber utensil was full of clots. The umbilical cord-untied-had slipped up into the vagina. I gave chloroform, and Mr. Sells removed a large number of blood-clots from the vagina, and eventually, but with great diffculty, managed to extract the placenta. The patient was quite blanched from loss of blood, complained of severe abdominal pain, and was in a state of almost total collapse. Ergot and opium were administered freely. Soon after the removal of the placenta the uterus contracted firmly, and no more blood was lost per vaginam. About an hour afterwards, however, the symptoms of shock became more pronounced, and on an examination of the abdomen being made a large mass was found occupying the site of the uterus. It was at first thought that the latter might be distended with clots, and it was accordingly washed out with warm boric solution. Nothing, however, came away. This was puzzling. A closer examination of the lower part of the abdomen revealed a large smooth elastic swelling in the hypogastric region, and on introducing the finger into the vagina a tumour could be distinctly felt pressing on this canal. Mr. Sells and I then came to the conclusion that this could be nothing else than a hæmatocele, due probably to an effusion of blood from some ruptured ressel into the sub-peritoneal tissue around the uterus. A smaller swelling was discovered to the left of the central one-apparently a smaller hrmatocele due to an effusion of blood in the course of the broad ligament. Nothing could be done except to keep the patient perfectly quiet in bed, support her strength, and administer opiates to relieve the pain and restlessness. She remained in an alarmingly weak state for some days, and suffered from profuse perspirations-generally in the early morning-and from frequent attacks of distressing vomiting. The temperature varied from $100^{\circ}$ to $102^{\circ} \mathrm{F}$, and the pulse was very weak and rapid. The smaller swelling cleared up in about a month. Shortly before this disappeared another appeared in the right iliac region and was attended with a good deal of abdominal tenderness and pain and distressing tympanites. The temperature rose to nearly $104^{\circ}$. This was probably an attack of pelvic cellulitis with subacute peritonitis, and it subsided in about a week under the free administration of opium and hot fomentations. The further history of the case-a dreadfully harassing and trying one to the patient and to her attendantsmay be briefly summarised. The prominent symptoms were frequent profuse sweats, distressing irritability of the stomach, obstinate constipation, occasional attacks of severe abdominal pain, and constant tympanites. The temperature generally varied between $100^{\circ}$ and $103^{\circ}$, though sometimes touching $104^{\circ}$, and the pulse was always very rapid-115 to 130-and occasionally of a running character difficult to count. The irritability of the stomach was so great that it was with extreme difficulty she kept down any nourishment. She became reduced to an alarming state of exhaustion and emaciation, and it was only after trying many kinds of food and stimulant that ve succeeded in finding some that could be retainet. These were the only things she could retain, and they enabled her to bear up successfully against her wasting illness. About the beginning of December the tumour, which had never 